\title{
Carbon Sequestration in Coastal Soils under Different Land Use in Schleswig-Holstein, Northern Germany
}

\author{
Normah AWANG BESAR (Corresponding author) \\ University of Hamburg, Institute of Soil Science \\ Allende-Platz 2, 20146 Hamburg, Germany \\ $\&$ \\ Current address: School of International Tropical Forestry \\ Universiti Malaysia Sabah, Jalan UMS \\ 88400 Kota Kinabalu, Sabah, Malaysia
}

Tel: 06-088-320-404 E-mail: normabr@ums.edu.my,warqa1@yahoo.com

Christian Knoblauch

University of Hamburg, Institute of Soil Science

Allende-Platz 2, 20146 Hamburg, Germany

Tel: 49-404-2838-2277 E-mail: Christian.knoblauch@uni-hamburg.de

Eva-Maria Pfeiffer

University of Hamburg, Institute of Soil Science

Allende-Platz 2, 20146 Hamburg, Germany

Tel: 49-404-2838-4194Ｅ-mail: E.M.Pfeiffer@ifb.uni-hamburg.de

Received: September 26, $2011 \quad$ Accepted: November 9, $2011 \quad$ Published: December 1, 2011

doi:10.5539/enrr.v1n1p53

URL: http://dx.doi.org/10.5539/enrr.v1n1p53

\begin{abstract}
Carbon sequestration was studied in the coastal soils of the "Katinger Watt", a former tidal flat of the North Sea coast in Schleswig-Holstein, Northern Germany. Carbon sequestration was determined by the ecological approach and calculated as the difference between total annual net primary production and total annual heterotrophic respiration. The measurement was conducted every month from June 2006 to May 2007. All sites were underlain by very young soils that developed after the former marine tidal flat was diked in 1973. After diking, the soils were drained and terrestrial soil formation continued for 35 year. The initial conditions after diking were similar in all sites. All soils were classified as Normkalkmarsch according to the German soil classification, as Calcic Fluvisol (WRB, 2007) and as Typic Fluvaquent (USDA, 2010). The annual carbon sequestration in the arable land was estimated as $-0.82 \mathrm{t} \mathrm{C} \mathrm{ha}^{-1} \mathrm{yr}^{-1}$ which indicates that the arable land acted as a net $\mathrm{CO}_{2}$ source during the investigation period. In the grassland, about $0.18 \mathrm{tC} \mathrm{ha}^{-1} \mathrm{yr}^{-1}$ was sequestered in the soil. In other words the grassland acted as a carbon sink during the investigation period.
\end{abstract}

Keywords: Carbon sequestration, Arable land, Grassland, Heterotrophic respiration, Net primary production

\section{Introduction}

Soils are the largest reservoir of carbon in the terrestrial ecosystem. They contain more than four times the amount available in the biotic pool and about three times more than the amount in the atmospheric pool (Lal, 2004a). The type of land use, soil cultivation techniques (John et al., 2005, Six et al., 2002), and management practice are important factors in controlling organic carbon storage in soils (Smith, 2004; Tan \& Lal, 2005). In addition, abiotic factors such as temperature and water contents influence carbon sequestration by affecting soil microbial activity and plant productivity (Jones et al., 2006). 
Carbon sequestration is defined as the removal of atmospheric $\mathrm{CO}_{2}$ by photosynthesis and the storage of fixed carbon in plant biomass and soil organic matter (Lal, 2004b), thereby storing $\mathrm{CO}_{2}$ in different carbon pools of varying lifetime (Jones \& Donnelly, 2004). These carbon pools are comprised of living and dead above and below ground biomass, wood products and soil organic matter.

Carbon sequestration in soils can be investigated directly by measuring changes in carbon pools, and indirectly by using ${ }^{13} \mathrm{C}$ as a tracer, or by using simulation modeling (Jones \& Donnelly, 2004). In this study, carbon sequestration was determined by direct measurements based on an ecological approach. In this approach the annual net primary production (NPP) and the net ecosystem production (NEP) was determined. Net ecosystem production equals carbon sequestration in the ecosystem which was determined from the difference between net primary production and heterotrophic respiration $\left(\mathrm{R}_{\mathrm{h}}\right)$ (Jones \& Donnelly, 2004; Schulze et al., 2002; Schulze et al., 2000; Verburg et al., 2004).

The impact of land use on carbon sequestration was studied in the coastal Nature Reserve "Katinger Watt", a diked young marshland at the North Sea in Schleswig-Holstein, Northern Germany. The site was a former sea-floor of a tidal flat that was diked 35 years ago when the Eider flood-barrier was built. Since the terrestrial soils in this area have a very short history, homogeneous conditions, and different land uses, the Katinger Watt sites are very suitable for field studies on the impact of land use on carbon sequestration. The main objective in this study was to characterize the effect of land use on carbon sequestration in coastal soils of the Katinger Watt. Two land use types (arable land and grassland) typical for the Katinger Watt were investigated in the presented study.

\section{Materials and Methods}

Two different land use types on the investigation area in the Katinger Watt were chosen for this investigation. These study sites are arable land and grassland. The arable land sampling site is located at the position 3491163 E, $6018500 \mathrm{~N}$, and the grassland sampling site at the position $3491735 \mathrm{E}, 6016357 \mathrm{~N}$.

Soil samples were taken every month between June 2006 and May 2007 at the respective study site. Mixed soil samples were collected from soil depths of 0-5 cm, 5-10 cm and 10-30 cm and stored in plastic bags. Mixed soil samples were sieved through a $2 \mathrm{~mm}$ mesh and plant residues and roots were removed. Undisturbed soil samples were collected in $100 \mathrm{ml}$ cylindrical steel cylinders $(10 \mathrm{~cm}$ diameter $)$ for bulk density. The total soil carbon content was determined by a CNS elemental analyser (Elementar, Vario Max) using milled samples. Soil inorganic carbon was quantified by gas chromatography after treatment with phosphoric acid. The organic carbon content was calculated as the difference between total and inorganic carbon

For measurements of heterotrophic respiration, soil samples were stored in the refrigerator at $4^{\circ} \mathrm{C}$ and analysed as soon as possible after sampling. Heterotrophic respiration $\left(\mathrm{R}_{\mathrm{h}}\right)$ was measured by a Sapromat respirometer equipped with 12 measuring channels (VOITH -SULZER, Ravensburg; Germany) at $22^{\circ} \mathrm{C}$ for $24 \mathrm{~h}$. The temperature response of heterotrophic respiration was measured by incubating soil samples from the arable land and grassland at $9^{\circ} \mathrm{C}, 12^{\circ} \mathrm{C}, 18^{\circ} \mathrm{C}$ and $25^{\circ} \mathrm{C}$ in the Sapromat and quantifying $\mathrm{CO}_{2}$ production. Subsequently the rates for heterotrophic respiration at different temperatures were fitted to the Arrhenius equation.

To identify plant species at the grassland site, a inventory was carried out in June 2007. On four quadrates (one square meter each) plant species were identified, their abundance quantified and the ecological key for vegetation identified.

To determine the plant biomass in the grassland and arable land three quadrates $\left(0.0625 \mathrm{~m}^{2}\right)$ were randomly selected in each study site. A steel frame $(25 \times 25 \mathrm{~cm})$ was pushed into the soil to define the sampling area. Above ground biomass in the quadrate was clipped at the soil surface and sampled in plastic bags. All material was sorted in the laboratory. Grass biomass was separated into live leaves and litter (including standing dead). At the arable land, rapeseed was separated into live leaves, stem, seeds and litter (including standing dead) and wheat was separated into live leaves and litter (including standing dead).Below ground plant biomass was sampled by collecting the soil in the steel frame down to a depth of $30 \mathrm{~cm}$ after removing all above ground plant biomass. These samples were washed over a $2 \mathrm{~mm}$ sieve to remove the mineral soil and subsequently sorted into coarse roots $(>2 \mathrm{~mm})$ and fine roots $(<2 \mathrm{~mm})$. All plant biomass samples were dried at $70^{\circ} \mathrm{C}$ for $72 \mathrm{~h}$ and then weighed, milled and carbon was determined with an CNS elemental analyser (Elementar, Vario Max) as described above for the soil samples.

Soil temperature was measured at the surface and in depths of $2 \mathrm{~cm}, 5 \mathrm{~cm}, 10 \mathrm{~cm}, 15 \mathrm{~cm}$ and $20 \mathrm{~cm}$ with a portable temperature probe ( $\mathrm{SiKA})$. 


\section{Results and Discussion}

The monthly net primary production was calculated from the changes in plant biomass between each sampling time. The monthly net primary production (NPP) in the arable land is presented in Figure 1. Between June and July 2007 NPP was positive due to a net increase of plant biomass during growth. It became negative in August 2006 due to harvest of rapeseed and stayed negative until the wheat seedlings started to grow significantly. The annual net primary production (NPP) was calculated from the sum of monthly NPP. Total NPP for rapeseed and wheat was $170 \mathrm{~g} \mathrm{C} \mathrm{m}^{-2} \mathrm{yr}^{-1}$ and $536 \mathrm{~g} \mathrm{C} \mathrm{m}^{-2} \mathrm{yr}^{-1}$, respectively giving the sum of an annual NPP of $706 \mathrm{~g} \mathrm{C} \mathrm{m}^{-2}$ $\mathrm{yr}^{-1}$.

In the grassland (Figure 1), the growth season peaked in June 2006 with a maximum NPP of $212 \mathrm{~g} \mathrm{C} \mathrm{m}^{-2}$. Due to mowing in July 2006 the above ground NPP was negative resulting in a low total NPP of $18 \mathrm{~g} \mathrm{C} \mathrm{m}^{-2}$. The growing season ended in October 2006 indicated by a steep drop of NPP from $91 \mathrm{~g} \mathrm{C} \mathrm{m}^{-2}$ to $-195 \mathrm{~g} \mathrm{C} \mathrm{m}^{-2}$ in November 2006 which was the lowest value measured during the whole investigation period. Between November 2006 and January 2007 the grassland was a net carbon source but in February 2007 NPP became positive again and increased until May 2007. The annual net primary production was calculated from the sum of monthly NPP and was $420 \mathrm{~g} \mathrm{C} \mathrm{m}^{-2} \mathrm{yr}^{-1}$. Total above ground NPP was $134 \mathrm{~g} \mathrm{C} \mathrm{m}^{-2} \mathrm{yr}^{-1}$ and total below ground NPP $286 \mathrm{~g} \mathrm{C} \mathrm{m}^{-2} \mathrm{yr}^{-1}$.

The grassland inventory identified the representative plant species at the grassland site. There was a very high covering range between 86 to $96 \%$. Plant species in the grassland belonged to grasses, herbs, orchids, mosses and shrubs. The grassland was dominated by herbaceous vegetation such as red clover (Trifolium pretense) with $16 \%, 11 \%$ of white clover (Trifolium repens), $13 \%$ creeping buttercup (Ranunculus repens), and $8 \%$ burr medick (Medicago minima) and $1 \%$ European yellowrattle (Rhinanthus alectorolophus). Grass species were dominated by $10 \%$ of red fescue (Festuca rubra), $7 \%$ common velvetgrass (Holcus lanatus), $6 \%$ meadow fescue (Festuca pratensis) and creeping bentgrass (Agrostis stolonifera), respectively. There were orchids such as health spotted-orchid (Dactylorhiza maculatea) and marsh Helleborine (Epipactris palustris). Dactylorhiza maculata grow in basic soils in wet meadows, bogs, health land and in areas sparsely populated by trees. Epipactris palustris is a rather scarce plant of lowland alkaline marshes, preferring sites which are seasonally inundated by water. The vegetation species showed that the site were calcareous, alkaline and wet. High soil moisture and $\mathrm{pH}$ (7-8) was indicated by species such as common reed (Phragmites australis), health spotted-orchid (Dactylorhiza maculate), longbract sedge (Carex extensa), distant sedge (Carex distans), and marsh Helleborine (Epipactris palustris).

\subsection{Heterotrophic respiration under arable land and grassland}

Heterotrophic respiration rates $\left(R_{h}\right)$ were measured between June 2006 and May 2007 in the uppermost $30 \mathrm{~cm}$ of the arable land soil. Since soil temperature varied considerably during the investigation period but heterotrophic respiration was measured routinely at $22^{\circ} \mathrm{C}$ in the laboratory the temperature response of heterotrophic respiration in the arable land was measured and the obtained data fitted to the Arrhenius equation. To calculate the rates of heterotrophic respiration at the respective in situ soil temperature (see Figure 3) the rates measured at $22^{\circ} \mathrm{C}$ in the laboratory were corrected with the fitted Arrhenius equation. The calculated activation energy (Ea) of heterotrophic respiration was $35 \mathrm{~kJ} / \mathrm{mol}$ (Figure 2).

The heterotrophic respiration $\left(\mathrm{R}_{\mathrm{h}}\right)$ rates were generally lower in the winter season and increased in summer (Figure 3). However, highest rates were measured in September $2006\left(132 \mathrm{mg} \mathrm{CO}_{2}-\mathrm{C} \mathrm{m}^{-2} \mathrm{~h}^{-1}\right)$ after rapeseed was harvested and the soil was ploughed. Minimum values were measured in October 2006 with $33 \mathrm{mg}$ $\mathrm{CO}_{2} \mathrm{~m}^{-2} \mathrm{~h}^{-1}$.

Between June 2006 and May 2007, $788 \mathrm{~g} \mathrm{C} \mathrm{m}^{-2}$ were mineralized by heterotrophic respiration. The soil water content varied between 11 and $25 \%$ and the soil temperature between 6 and $22^{\circ} \mathrm{C}$ in the uppermost $5 \mathrm{~cm}$ of the soil (Figure 3).

As in the arable land, the temperature response of heterotrophic respiration rates $\left(\mathrm{R}_{\mathrm{h}}\right)$ were measured at $22^{\circ} \mathrm{C}$ and the results were corrected to the respective in situ temperature (Figure 2). The calculated activation energy (Ea) of heterotrophic respiration was $294 \mathrm{~kJ} / \mathrm{mol}$.

Heterotrophic respiration $\left(R_{h}\right)$ was highest in summer and decreased in winter (Figure 3) $R_{h}$ peaked with $126 \mathrm{mg}$ $\mathrm{CO}_{2}-\mathrm{C} \mathrm{m}^{-2} \mathrm{~h}^{-1}$ in September 2006 and decreased throughout autumn. The minimum values were measured in January $2007\left(2 \mathrm{mg} \mathrm{CO}_{2}-\mathrm{C} \mathrm{m}^{-2} \mathrm{~h}^{-1}\right)$ when the temperature was lowest.

Total annual heterotrophic respiration, i.e. organic matter mineralization, was $402 \mathrm{~g} \mathrm{C} \mathrm{m}^{-2}$. Soil temperature varied between 5 and $24^{\circ} \mathrm{C}$ and soil water content varied between 6 and $59 \%$. 
Heterotrophic respiration rate decreased with soil depth in the grassland but not in the arable land due to tillage. This was also reported in recent studies (Dilly et al., 2005; Kaiser \& Heinemeyer, 1993). The seasonal pattern of heterotrophic respiration was similar in all different land uses. The heterotrophic respiration rate was highest in the growing period and lowest in the winter season. Similar result were found by Kaiser and Heinemeyer (1993) and Dilly (2003). Soil temperature was an important factor controlling the monthly changes in heterotrophic respiration within the investigation sites. Several previous studies have shown that soil temperature is an important factor controlling soil respiration (Buchmann, 2000; Janssens et al., 2001; Yazaki et al., 2004). Total annual heterotrophic respiration rates in the uppermost $30 \mathrm{~cm}$ were significantly different depending on the type of land use. Total annual heterotrophic respiration was highest in the arable land $\left(7.88 \mathrm{t} \mathrm{Cha}^{-1} \mathrm{yr}^{-1}\right)$ followed by the grassland $\left(4.02 \mathrm{tC} \mathrm{ha}^{-1} \mathrm{yr}^{-1}\right)$.

\subsection{Carbon sequestration under arable land and grassland}

Carbon sequestration equals the net ecosystem production and was calculated as the difference between NPP and heterotrophic respiration. The seasonal change in the carbon sequestration is presented in Figure 4. The carbon sequestration clearly increased in the growing season and decreased in the autumn and winter season.

In arable land carbon sequestration was positive $\left(\mathrm{CO}_{2}\right.$ uptake by plant) in June and July 2006 and became negative (net release of $\mathrm{CO}_{2}$ to the atmosphere) between August $2006\left(-295 \mathrm{~g} \mathrm{C} \mathrm{m}^{-2}\right)$ and February 2007 when the rapeseeds were harvested and growth of the seeded wheat was small. With beginning of the growing season in March 2007 carbon sequestration became positive reaching maximum values of $272 \mathrm{~g} \mathrm{C} \mathrm{m}^{-2}$ in May 2007 . The annual carbon sequestration was estimated as $-82 \mathrm{~g} \mathrm{C} \mathrm{m}^{-2}$ which indicates that the arable land acted as a net $\mathrm{CO}_{2}$ source during the investigation period.

In the grassland (Figure 4), Carbon sequestration was highest in June $2006\left(107 \mathrm{~g} \mathrm{C} \mathrm{m}^{-2}\right)$ and became negative in July $\left(-78 \mathrm{~g} \mathrm{C} \mathrm{m}^{-2}\right)$ and August $2006\left(-39 \mathrm{~g} \mathrm{C} \mathrm{m}^{-2}\right)$ which was due to mowing and harvest of the grass. In September and October 2006 a net carbon sequestration was measured while a net carbon release was observed between November $2006\left(-200 \mathrm{~g} \mathrm{C} \mathrm{m}^{-2}\right)$ and January 2007. Annual carbon sequestration was $18 \mathrm{~g} \mathrm{C} \mathrm{m}^{-2}$. In other words the grassland acted as a $\mathrm{C}$ sink during the investigation period.

Carbon sequestration in this study decreased in the order: grassland $>$ arable land and ranged between -82 and $+18 \mathrm{~g} \mathrm{C} \mathrm{m}^{-2} \mathrm{yr}^{-1}$. Similar result were reported by several recent studies which demonstrated that carbon sequestration was highest in grassland, followed by arable land with only the arable land being a net carbon source (Janssens et al., 2005; Liski et al., 2002; Sleutel et al., 2003; Vleeshouwers \& Verhagen, 2002). Carbon sequestration was quantified in two Spartina marshes by Middelburg et al. (1997). They measured an annual carbon burial of 96-105 $\mathrm{g} \mathrm{C} \mathrm{m}^{-2} \mathrm{yr}^{-1}$.

Estimates on carbon sequestration in the arable land have the largest uncertainties among all land use systems (Janssens et al., 2003; Smith, 2004). In arable land, carbon losses are caused by harvest, reducing the amount of carbon being released into the soil, and agricultural practices such as tillage, ploughing, drainage etc. (Janssens et al., 2005). Furthermore land use changes such as conversion of pasture to cropland, and increasing temperatures result in an increasing release of $\mathrm{CO}_{2}$ from arable land (Sleutel et al., 2006). Additionally, various crop types will lead to large differences in the carbon sequestration even in a scale of small fields (Anthoni et al., 2004).

During the investigation period the grassland acted as carbon sink with a strength of $0.18 \mathrm{t} \mathrm{C} \mathrm{ha}^{-1} \mathrm{yr}^{-1}$. One reason for the relatively small carbon sequestration was the removal of a considerable part of the above ground biomass by mowing for producing hay and sheep grazing. The frequency and intensity of disturbance plays an important role in the carbon sequestration in grasslands (Soussana et al., 2007). Via hay or silage production, a large amount of the primary production is exported from the plot as hay and silage. The largest part of the organic carbon ingested during grazing is digestible (up to $75 \%$ for highly digestible forages) and hence is respired shortly after intake. A negative carbon sequestration rate was reported by Yazaki et al. (2004) for a Miscanthus sinensis grassland in Japan with a net carbon release of -0.56 to $-1.0 \mathrm{t} \mathrm{Cha}^{-1} \mathrm{yr}^{-1}$. However, using a similar approach as the present study, Kleber (1997) reported carbon sequestration in fertilized grassland ranging between -0.1 to $5.6 \mathrm{t} \mathrm{C} \mathrm{ha}^{-1} \mathrm{yr}^{-1}$ and carbon sequestration under grassland was quantified in Australia, UK, New Zealand, Canada, Brazil and the United States between 0.11 to $3.0 \mathrm{tC} \mathrm{ha}^{-1} \mathrm{yr}^{-1}$ with a mean of $0.54 \mathrm{t} \mathrm{C} \mathrm{ha}^{-1} \mathrm{yr}^{-1}$ (Conant et al., 2001). However, previous estimates on carbon sequestration in the same grassland as we studied, Dilly et al. (2005) are with $0.90 \mathrm{t} \mathrm{C} \mathrm{ha}^{-1} \mathrm{yr}^{-1}$ considerably higher than the values that we found. However in latter study carbon sequestration was estimated solely from grassland carbon pools assuming that $100 \%$ of the organic carbon was accumulated in the 34 years after diked. The present study however demonstrates, that Dilly et al. (2005) used a sampling site with an over-average carbon content, resulting in an 
overestimation of the total organic carbon pool in the grassland, resulting in the calculation of a carbon sequestration rate which is too high. Furthermore, the carbon sequestration rates seem to be not linear over the last 30 years but decreased after considerable amounts of organic carbon has been accumulated. It is assumed that the relatively low carbon sequestration rates determined in the current study give a more realistic assumption on carbon fluxes under current situation than the calculations of Dilly et al. (2005).

\section{Conclusion}

Carbon sequestration was determined by the ecological approach and calculated as the balance between total annual NPP and total annual heterotrophic respiration. The annual carbon sequestration in the arable land was estimated as $-0.82 \mathrm{t} \mathrm{C}^{-1} \mathrm{yr}^{-1}$ which indicates that the arable land acted as a net $\mathrm{CO}_{2}$ source during the investigation period. In the grassland, about $0.18 \mathrm{t} \mathrm{C} \mathrm{ha}^{-1} \mathrm{yr}^{-1}$ was sequestered in the soil. In other words the grassland acted as a $\mathrm{C}$ sink during the investigation period.

\section{Acknowledgements}

The authors would like to thank ChristophRabeler for support at the field sites, BartoszKaczmarek, Maximilian Hofmeier, and Claudia Fienckefor help with field sampling and Susanne Kopelke, Birgit Grabellus and Birgit Schwinge for support with laboratory analysis. This study was conducted with financial support from the Universiti Malaysia Sabah, Malaysia and the Malaysian Government to Normah Awang Besar.

\section{References}

Anthoni, P. M., A. Knohl, C. Rebmann, A. Freibauer, M. Mund, W. Ziegler, O. Kolle, \& E.-D. Schulze. (2004). Forest and agricultural land-use-dependent $\mathrm{CO}_{2}$ exchange in Thuringia, Germany. Global Change Biology, 10, 2005-2019. http://dx.doi.org/ 10.1111/j.1365-2486.2004.00863.x

Buchmann, N. (2000). Biotic and abiotic factors controlling soil respiration rates in Picea abies stands. Soil Biology and Biochemistry, 32, 1625-1635. http://dx.doi.org/10.1016/S0038-0717(00)00077-8

Conant, R. T., K. Paustian, \& E. T. Elliott. (2001). Grassland management and conversion grassland: Effect on soil carbon. Ecological Applications, 11, 343-355. http://dx.doi.org/10.3334/CDIAC/tcm.005

Dilly, O., A. Gnaß, \& E.-M. Pfeiffer. (2005). Humus accumulation and microbial activities in calcari-epigleyic fluvisols under grassland and forest diked in for 30 years. Soil Biology and Biochemistry, 37, 2163-2166.

Dilly,O. (2003). Regulation of the respiratory quotient of soil microbiota by availability of nutrients. FEMS Microbiology Ecology, 43, 375-381. http://dx.doi.org/10.1111/j.1574-6941.2003 ...x

Janssens, I. A., A. Freibauer, B. Schlamadinger, R. Ceulemans, P. Ciais, A. J. Dolman, ... \& E.-D. Schulze. (2005). The carbon budget of terrestrial ecosystems at country-scale-a European case study. Biogeosciences, 2, 15-26._http://dx.doi.org/10.5194/bg-2-15-2005

Janssens, I. A., A. Freibauer, P. Ciais, P. Smith, G.-J. Nabuurs, G. Folberth, ... \& A. J. Dolman. (2003). Europe's Terrestrial Biosphere Absorbs 7 to $12 \%$ of European Anthropogenic $\mathrm{CO}_{2}$ Emissions. Science, 300, 1538-1542. http://dx.doi.org/10.1126/science.1083592

Janssens, I. A., H. Lankreijer, G. Matteucci, A. S. Kowalski, N. Buchmann, D. Epron, ... \& R. Valentini. (2001). Productivity overshadows temperature in determining soil and ecosystem respiration across European forests. Global Change Biology, 7, 269-278. http//dx.doi.org/10.1046/j.1365-2486.2001.00412.x

John, B., T. Yamashita, B. Ludwig, \& H. Flessa. (2005). Storage of organic carbon in aggregate and density fractions of silty soils under different types of land use. Geoderma. Mechanisms and regulation of organic matter stabilisation in soils, 128, 63-79. http://dx.doi.org/101016/j.geoderma.2004.12.013

Jones, S. K., R. M. Rees, D. Kosmas, B. C. Ball, \& U. M. Skiba. (2006). Carbon sequestration in a temperate grassland; management and climatic controls. Soil Use and Management, 22, 132-142. http://dx.doi.org/10.1111/j.1475-2743.2006.00036.x

Jones, M. B., \& A. Donnelly. (2004). Carbon sequestration in temperate grassland ecosystems and the influence of management, climate and elevated $\mathrm{CO}_{2}$. New Phytologist, 164, 423-439. http://dx.doi.org/10.1111/j.1469-8137.2004.01201.x

Kaiser, E.-A., \& O. Heinemeyer. (1993). Seasonal variations of soil microbial biomass carbon within the plough layer. Soil Biology and Biochemistry, 25, 1649-1655. http://dx.doi.org/10.1016/0038-0717(93)90166-9

Kleber, M. (1997). Carbon exchange in humid grassland soils (Kohlenstoffumsatz in Böden eines feuchten Grünlandstandortes). Dissertation. Universität Hohenheim, Germany. 244. 
Lal, R. (2005). Forest soils and carbon sequestration. Forest Ecology and Management. Forest Soils Research:

Theory, Reality and its Role in Technology - Selected and Edited Papers from the 10th North American Forest Soils Conference held in Saulte Ste. Marie, Ontario, Canada, 20-24 July 2003 220, 242-258.

Lal, R. (2004a). Soil carbon sequestration impacts on global climate change and food security. Science, 304, 1623-1627. http://dx.doi.org/10.1126/science.1097396

Lal, R. (2004b). Soil carbon sequestration to mitigate climate change. Geoderma, 123, 1-22. http://dx.doi.org/10.1016/j.geoderma.2004.01.032

Liski, J., D. Perruchoud, \& T. Karjalainen. (2002). Increasing carbon stocks in the forest soils of western Europe. Forest Ecology and Management, 169, 159-175. http://dx.doi.org/10.1016/S0378-1127(02)00306-7

Middelburg, J. J., J. Nieuwenhuize, R. K. Lubberts, \& O. van de Plassche. (1997). Organic Carbon Isotope Systematics of Coastal Marshes. Estuarine, Coastal and Shelf Science, 45, 681-687.

Schulze, E.-D., R. Valentini, \& M.-J. Sanz. (2002). The long way from Kyoto to Marrakesh: Implications of the Kyoto Protocol negotiations for global ecology. Global Change Biology, 8, 505-518. http://dx.doi.org/10.1046/j.1365-2486.2002.00523.x

Schulze, E.-D., C. Wirth, \& M. Heimann. (2000). Climate change: Managing Forests After Kyoto. Science, 289, 2058-2059. http://dx.doi.org/10.1126/science.289.5487.2058

Six, J., R. T. Conant, E. A. Paul, \& K. Paustian. (2002). Stabilization mechanisms of soil organic matter:Implications for C-saturation of soils. Plant and Soil, V241, 155-176.

Sleutel, S., S. De Neve, B. Singier, \& G. Hofman. (2006). Organic C levels in intensively managed arable soils long-term regional trends and characterization of fractions. Soil Use and Management, 22, 188-196. http://dx.doi.org/10.1111/j.1475-2743.2006.00019.x

Sleutel, S., S. De Neve, G. Hofman, P. Boeckx, D. Beheydt, O. Van Cleemput, ... \& R. Lemeur. (2003). Carbon stock changes and carbon sequestration potential of Flemish cropland soils. Global Change Biology, 9, 1193-1203. http://dx.doi.org/10.1046/j.1365-2486.2003.00651.x

Smith, P. (2004). Carbon sequestration in croplands: the potential in Europe and the global context. Europea Journal of Agronomy, 20, 229-236. http://dx.doi.org/10.1016/j.eja.2003.08.002

Soussana, J. F., V. Allard, K. Pilegaard, P. Ambus, C. Amman, C. Campbell, ... \& R. Valentini. (2007). Full accounting of the greenhouse gas $\left(\mathrm{CO}_{2}, \mathrm{~N}_{2} \mathrm{O}, \mathrm{CH}_{4}\right)$ budget of nine European grassland sites. Agriculture, Ecosystems \& Environment. The Greenhouse Gas Balance of Grasslands in Europe, 121, 121-134. http://dx.doi.org/10.1016/j.agee.2006.12.022

Tan, Z., \& R. Lal. (2005). Carbon sequestration potential estimates with changes in land use and tillage practice in Ohio, USA. Agriculture, Ecosystems \& Environment, 111, 140-152. http://dx.doi.org/10.1016/j.agee.2005.05.012

USDA. (2010). Keys to Soil Taxonomy, 11 ed. United States Department of Agriculture, Soil Survey Staff.

Verburg, P. S. J., J. A. Arnone, D. Obrist, D. E. Schorran, R. D. Evans, D. Leroux-swarthout, ... \& J. S. Coleman. (2004). Net ecosystem carbon exchange in two experimental grassland ecosystems. Global Change Biology, 10, 498-508. http://dx.doi.org/10.1111/j.1529-8817.2003.00744.x

Vleeshouwers, L. M., \& A. Verhagen. (2002). Carbon emission and sequestration by agricultural land use: a model study for Europe. Global Change Biology, 8, 519-530. http://dx.doi.org/10.1046/j.1365-2486.2002.00485.x

WRB, I.W.G. (2007). World Reference Base for Soil Resources, 2006, first update 2007. FAO, Rome

Yazaki, Y., S. Mariko, \& H. Koizumi. (2004). Carbon dynamics and budget in a Miscanthus sinensis grassland in Japan. Ecological Research, V19, 511-520. http://dx.doi.org/10.1111/j.1440-1703.2004.00665.x 

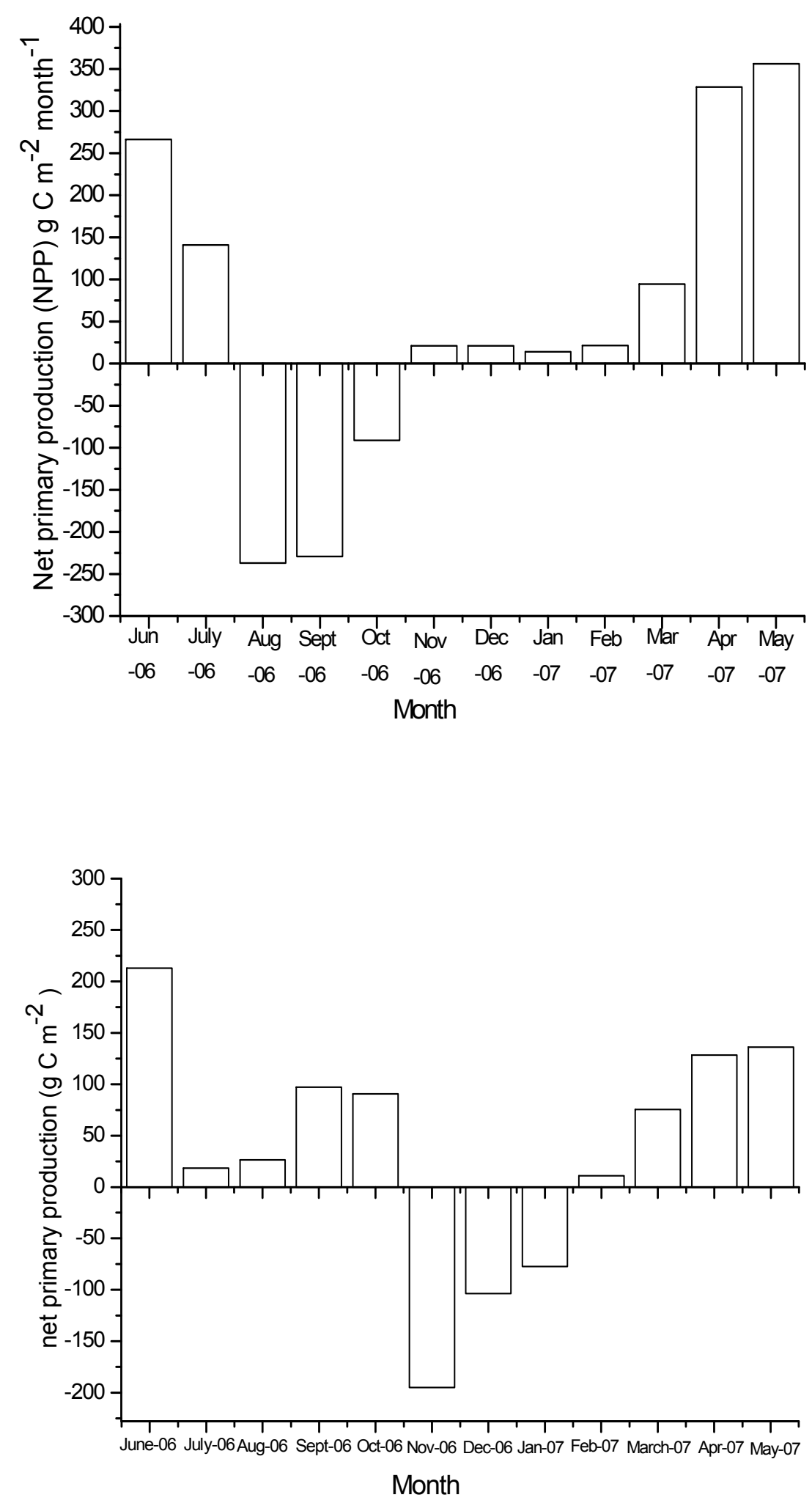

Figure 1. Monthly NPP from June 2006 to May 2007. Left is under arable land. Rapeseed grew between June 2006 and August 2006. In September 2007, wheat was seeded that started to grow in October 2007. Right is grassland 

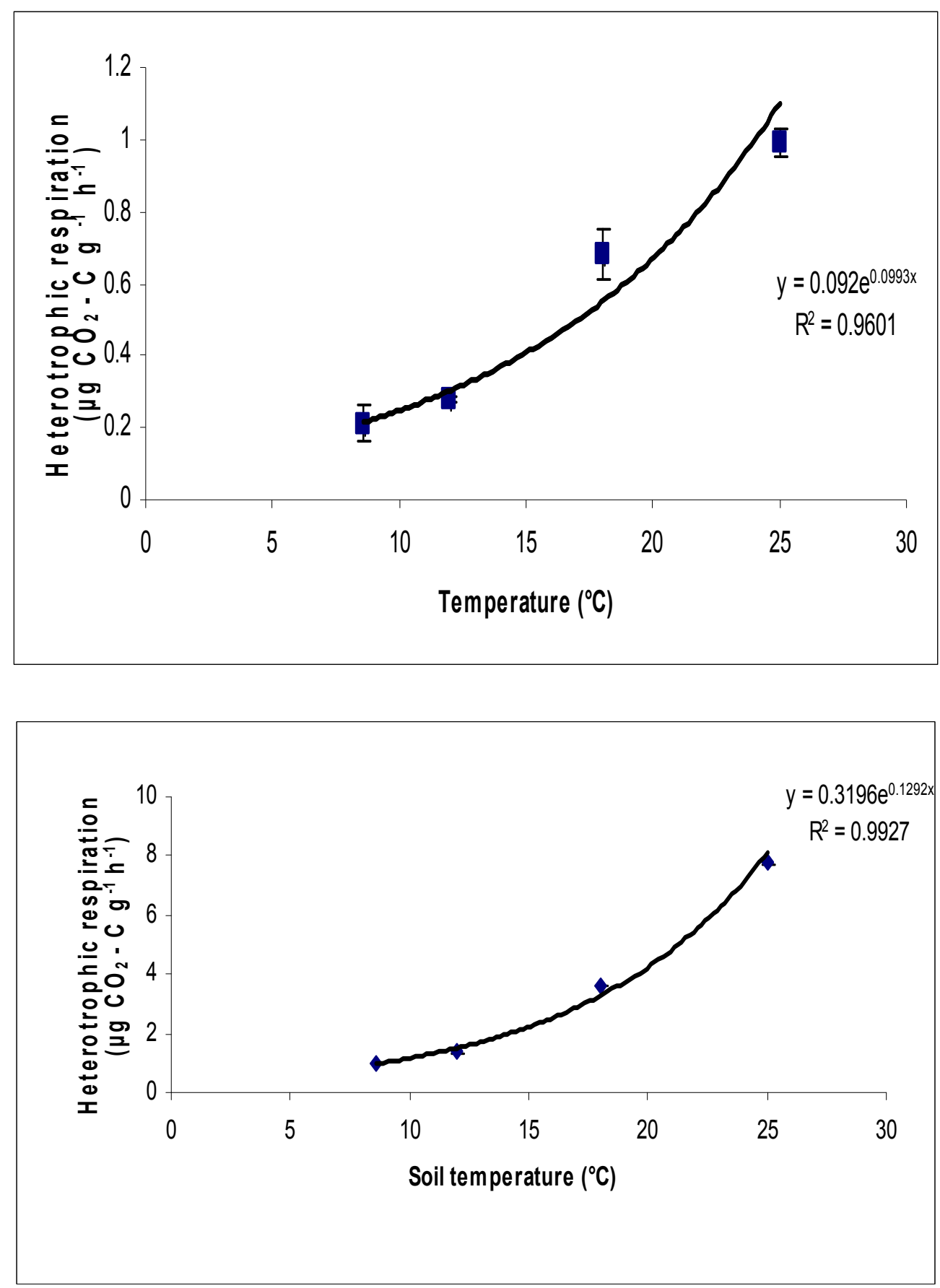

Figure 2. Temperature response of heterotrophic respiration in the arable land. Heterotrophic respiration rates were fitted to the Arrhenius equation. Error bars represent standard deviation for $n=3$. Right is temperature response of heterotrophic respiration in the grassland 

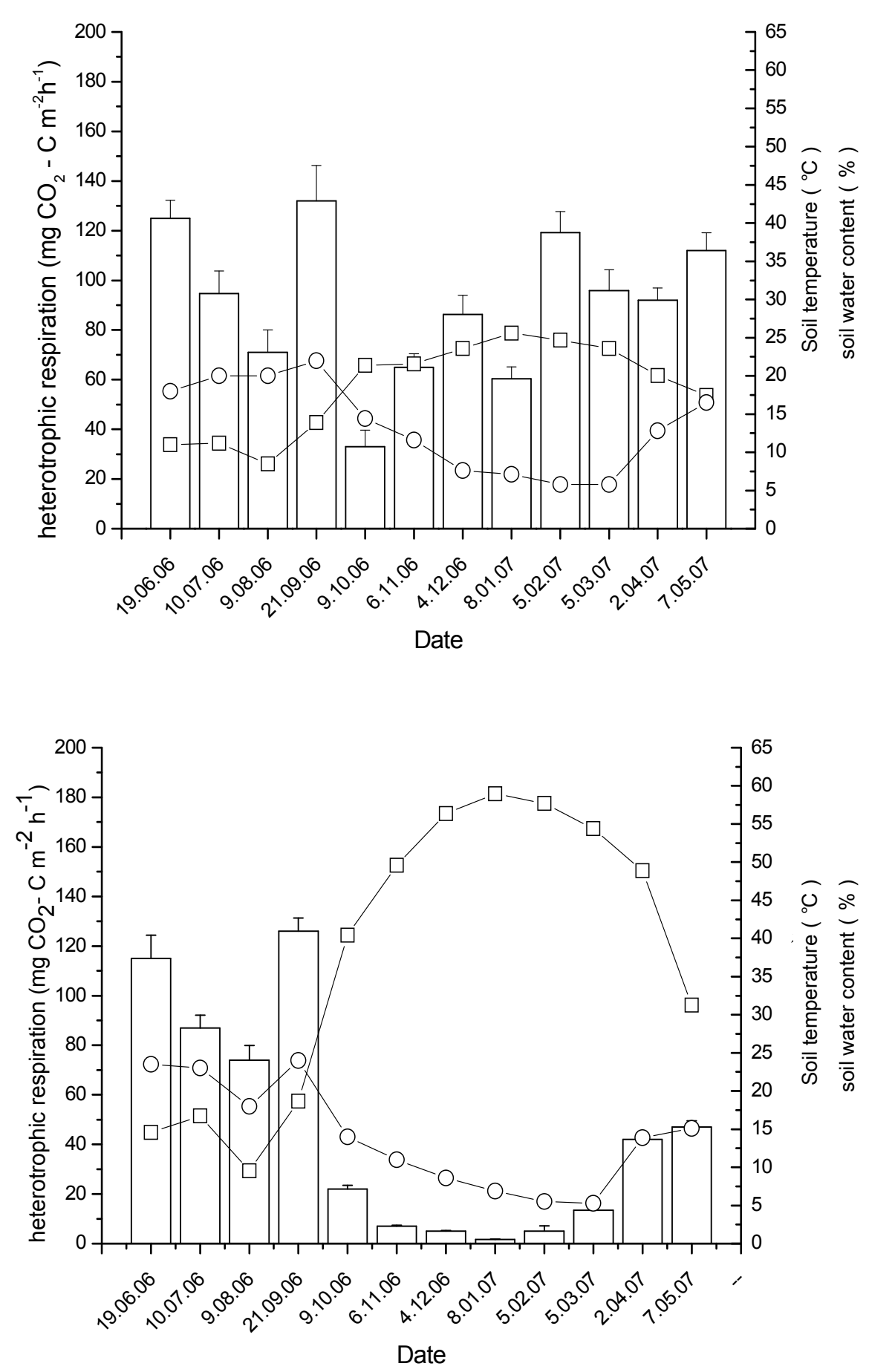

Figure 3. Monthly heterotrophic respiration rates in the uppermost $30 \mathrm{~cm}$ of the arable land (columns) that were corrected to the respective in situ temperature. Soil temperature at $5 \mathrm{~cm}$ depth (circle) and soil water content in the uppermost $5 \mathrm{~cm}$ (square). Error bars represent standard deviations for $\mathrm{n}=3$. Left is arable land and right is grassland 

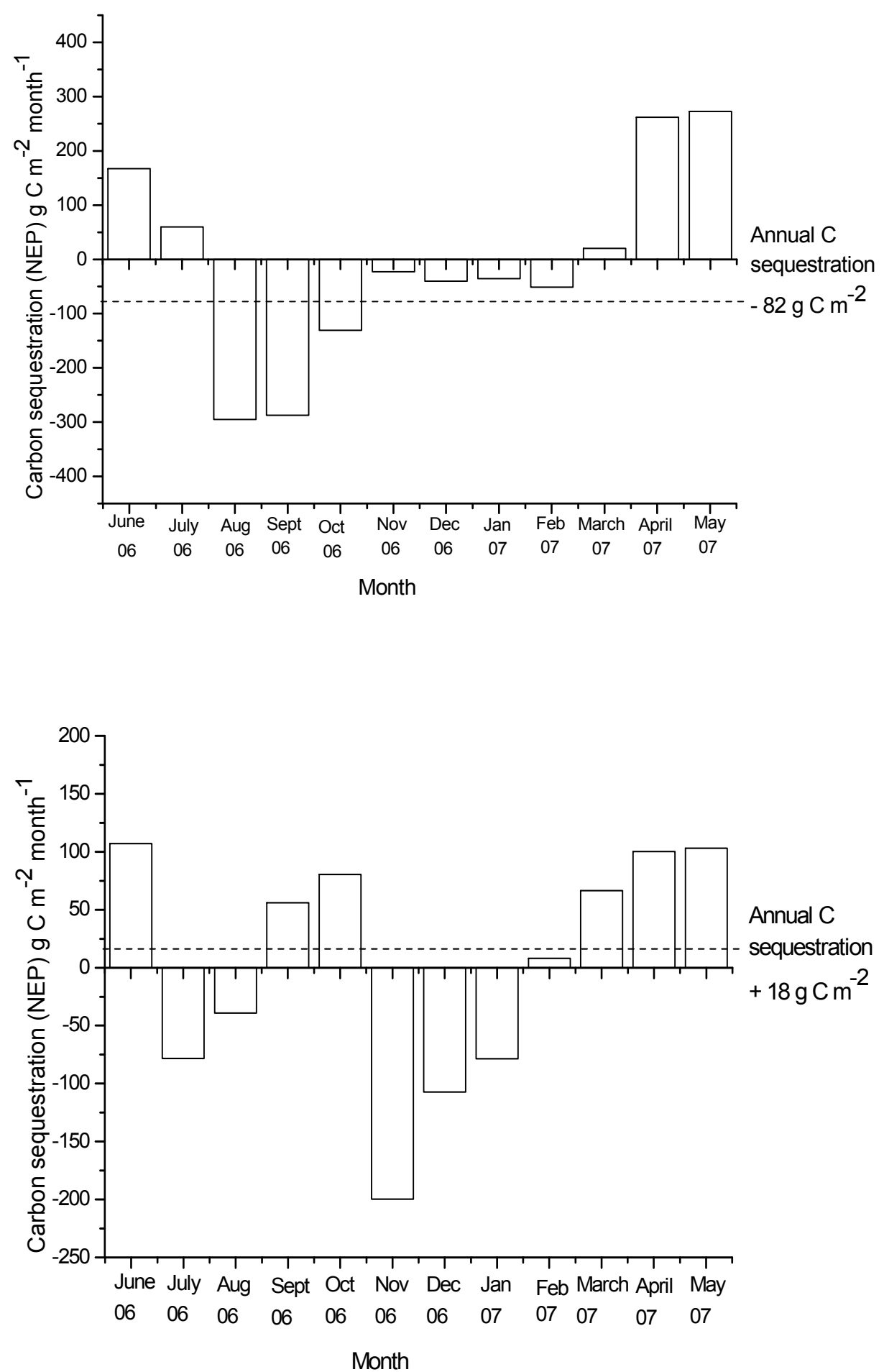

Figure 4. Monthly carbon sequestration between June 2006 and May 2007. Positive values represent $\mathrm{CO}_{2}$ uptake by plant (carbon sink) and negative values represent a net $\mathrm{CO}_{2}$ release by plant to atmosphere (carbon source).

Left is arable land and right is grassland 